\title{
Histological and Immunohistochemical Study on the Possible Effect of Mangosteen and Mesenchymal Stem Cells on Isoproterenol Induced Myocardial Infarction in Adult Male Albino Rats
}

Original
Article

\author{
Zeinab Mohamed Kamel Ismail, Mary Attia Morcos, Mohamed Diaa EL-Deen \\ Mohamed EL-Shafei and Fatma Al-Zahraa Mohamed Helmy
}

Department of Histology, Faculty of Medicine, Cairo University.

ABSTRACT

Background: Myocardial infarction (MI) is one of the causes of cardiovascular diseases that lead to death despite of the great advancements in the medical interventions.

Aim of the work: To assess the possible effect of mangosteen and mesenchymal stem cells (MSCs) in Isoproterenol (ISO)induced MI in adult male albino rats, monitored by histological and immunohistochemical methods.

Materials and Methods: Fifty-five adult male albino rats were divided into: control group (GI), group II (ISO), group III (Mangosteen+ISO), group IV (ISO+MSCs), group V (Mangosteen+Isoproterenol+MSCs). ISO was given subcutaneously, twice $(250 \mathrm{mg} / \mathrm{kg} / \mathrm{d})$, mangosteen was given orally $(18 \mathrm{mg} / 200 \mathrm{gm})$ and MSCs $\left(5 \times 10^{6}\right.$ cells in $1 \mathrm{~mL}$ of PBS) were injected intracardiac. Myocardial sections were stained with H\&E, Masson's trichrome and immunohistochemical stain for caspase-3 and vascular endothelial growth factor (VEGF). The mean area \% of collagen fibers and immunoreactivity of caspase- 3 and VEGF were measured by the image analyzer. The statistical analysis was applied by using ANOVA.

Results: Myocardial sections of G II revealed discontinuity and degeneration of cardiac muscle fibers, pyknotic nuclei, inflammatory cellular infiltration and congested blood vessels. There were increased collagen deposition and significant increase in caspase-3 immunoreactivity. Mangosteen administration (G III) showed partial improvement in cardiac muscle fibers and reduced inflammatory cellular infiltration.

MSCs treatment (G IV) resulted in obvious decline in myocardial damage, apoptosis with significant reduction of collagen deposition and significant increase in VEGF immunoreactivity. Better results are obtained when MSCs and mangosteen were combined $(\mathrm{G} \mathrm{V})$.

Conclusion: Mangosteen exerts a synergistic effect with MSCs against ISO-induced MI.

Received: 17 February 2019, Accepted: 20 February 2019

Key Words: Caspase-3, mangosteen, mesenchymal stem cells, myocardial infarction, VEGF

Corresponding Author: Fatma Al-Zahraa Mohamed Helmy, PhD, Histology Department, Faculty of Medicine, Cairo University, Cairo, Egypt, Tel.: +20 1006506003, E-mail: fatmahelmy1982@gmail.com

ISSN: 1110-0559, Vol. 42, No. 3

\section{INTRODUCTION}

Myocardial infarction (MI) is defined as irreversible ischemic injury or subsequent necrosis of myocardial cells, which leads to cardiac dysfunction and heart failure ${ }^{[1]}$.

Isoproterenol (ISO) is a beta-adrenoceptor agonist that causes imbalance between oxidants and antioxidants in the myocardium. It produces also free radicals that have been implicated in induced MI. Other theories include coronary vasospasm, dysfunction of mitochondria, changes in electrolytes, fatty acids and $\mathrm{Ca}^{+2}$ in addition to induction of apoptosis $^{[2]}$.

The stem cells could potentially be used to grow a particular type of tissue and improve the function of affected organs .Previous preclinical works submitted that mesenchymal stem cells (MSCs) have the possibility to differentiate into multiple cardiac cell types like cardiomyocytes, vascular endothelial cells, and vascular smooth myocytes ${ }^{[3]}$. Conversely, others suggested that
MSCs improve cardiac function via the secretion of paracrine factors such as vascular endothelial growth factor (VEGF) and hepatocyte growth factor ${ }^{[4]}$.

Mangosteen is a tropical fruit planted in Southeast Asia used in the traditional therapy of many diseases. Xanthones are the main secondary metabolites of mangosteen that display a variety of biological actions including antibacterial, anti-inflammatory, anti-oxidant and cancer chemopreventive ${ }^{[5]}$.

This work was planned to assess the effect of mangosteen and MSCs in ISO induced MI in adult male albino rats, monitored by histological and immunohistochemical methods.

\section{MATERIALS AND METHODS}

Drugs

a. Mangosteen (trade name): in a capsule form (the amount of the capsule is $500 \mathrm{mg}$ that contains $75 \mathrm{mg}$ 
15\% Alpha-Mangostin, 75mg 15\% tannins, 200mg 40\% flavonoids). The drug is manufactured by Savesta Life Sciences Inc., Chatsworth, CA 91311. The content of the capsule was dissolved in $2 \mathrm{ml}$ distilled water and given to the animal in a dose $18 \mathrm{mg}$ for a rat weighing $200 \mathrm{gm}$ according to Paget formula ${ }^{[6]}$.

b. Isoproterenol (ISO): (Sigma Corporation) in the form of powder. It was given, in a dose of $250 \mathrm{mg} / \mathrm{kg} /$ day dissolved in $0.5 \mathrm{ml}$ phosphate buffered saline (PBS), subcutaneously (SC) two times with an interval of 24 hours in between ${ }^{[7]}$.

\section{Animals}

Fifty-five adult male albino rats (age: 6-8 weeks \& weight: ranging from 170-200 grams) were bred in the Animal House of Physiology Department, Kasr Al Aini, Cairo University. Each group was kept in a separate wire cage at room temperature, fed with standard laboratory chow and had free access to tap water. All procedures were held under ethical guidelines for the Care and Use of Laboratory Animals of Cairo University.

\section{Experimental design}

\section{The rats were divided into the following groups}

Group I (Control group): Twenty rats were divided equally into 4 subgroups: Subgroup Ia received $0.5 \mathrm{ml}$ PBS (SC) two times with an interval of 24 hours. Subgroup Ib received $2 \mathrm{ml}$ distilled water orally for 6 days prior to the PBS injection. Subgroup Ic: as in subgroup Ia. After 2 weeks, $1 \mathrm{ml}$ of PBS was injected into the left ventricular wall (LVW). Subgroup Id: as in subgroup Ib. After 2 weeks another $1 \mathrm{ml}$ of PBS was injected into the LVW. Rats were sacrificed with their corresponding experimental groups.

Group II (Isoproterenol): Ten rats, each rat received 250 $\mathrm{mg} / \mathrm{kg} /$ day ISO dissolved in $0.5 \mathrm{ml} \mathrm{PBS}, \mathrm{SC}$ two times with an interval of 24 hours $^{[7]}$. The rats were sacrificed after 2 weeks (Subgroup IIa) and after 6 weeks (Subgroup IIb).

Group III (Mangosteen + Isoproterenol): Five rats, each rat received mangosteen $(18 \mathrm{mg} / 200 \mathrm{gm}$ body weight according to paget formula $)^{[6]}$ dissolved in $2 \mathrm{ml}$ distilled water, orally via intragastric tube for 6 days before ISO injection as in GII. Mangosteen administration continued till the end of the experiment. The rats were sacrificed after 6 weeks.

Group IV (Isoproterenol + MSCs): Ten rats received ISO injection as in GII. After 2 weeks, bone-marrow derived MSCs $\left(5 \times 10^{6}\right.$ cells in $1 \mathrm{~mL}$ of PBS) were injected into the $\mathrm{LVW}^{[8]}$ via a longitudinal incision in the chest wall at the end of the sternum. The rats were sacrificed after 6 days (Subgroup IVa) and after one month (Subgroup IVb) from MSCs injection (6 weeks after ISO).

Group V (Mangosteen + Isoproterenol + MSCs): Ten rats received mangosteen and ISO as in G III. Mangosteen was administrated along the experiment till the rats' sacrification. After 2 weeks from the last injection of
ISO, MSCs $\left(5 \times 10^{6}\right.$ cells in $1 \mathrm{~mL}$ of PBS). The rats were sacrificed after 6 days (Subgroup Va) and after one month (Subgroup $\mathrm{Vb}$ ) from MSCs injection (6 weeks after ISO).

\section{BM-derived MSCs Isolation and Culture ${ }^{[9]}$}

The primary BM cells were obtained from the long bones of 8 weeks old male albino rat by aspiration. Dulbecco's Modified Eagle's medium (DMEM) (Sigma, USA, D5796) was used containing 10\% fetal bovine serum (FBS) (Sigma, USA, F6178) with antibiotic-antimycotic reagent, L-glutamine and D-glucose at $37 \mathrm{oC}$ in a humidified atmosphere that contained 5\% CO2. Twenty four hours later, the non-adherent cells were eliminated by changing the culture medium. The adherent cells were expanded by serial passages. Cells were used for the experiment after the third passage.

MSCs in culture were characterized by their adhesiveness and fusiform shape and by detection of CD29 one of surface markers of rat mesenchymal stem cell ${ }^{[10]}$.

\section{Labelling of stem cells with PKH26 dye}

MSCs cells were labeled with PKH26 fluorescent linker dye. PKH26 Red Fluorescent Cell Linker Kit (SigmaAldrich) (Catalog Numbers MINI26 and PKH26GL). Labelled cells retain both biological and proliferating activity, and are ideal for invitro cell labelling, invitro proliferation studies and long term, invivo cell tracking ${ }^{[11]}$. The cells were examined using fluorescence microscopy (Olympus BX-50 f4, Olympus Optical Co.Ltd., Japan. No.7MO3285).

\section{Histological study}

All animals were sacrificed by an intraperitoneal injection of thiopental sodium $500 \mathrm{mg}(50 \mathrm{mg} / \mathrm{kg}$ body weight) at the end of various durations ${ }^{[12]}$.

Specimens from the apex of the left ventricle were obtained by performing a chest incision and were fixed in $10 \%$ buffered formalin solution for 48 hours. Paraffin blocks were prepared and $5 \mu \mathrm{m}$ thick sections were subjected to:

I-Detection of the PKH26 labeled MSCs with fluorescent microscope: Unstained sections were examined by Olympus BX-50 f4, Olympus Optical Co.Ltd., Japan. No.7MO3285 in MSCs treated groups.

II-Light Microscopic Study:

1. Haematoxylin and Eosin (H\&E) Staining ${ }^{[13]}$.

2. Masson's trichrome to stain collagen fibers ${ }^{[14]}$.

3. Immunohistochemical staining for:

a. Caspase-3 antibody for detection of apoptotic cells.

b. Vascular endothelial growth factor (VEGF) to detect angiogenesis.

These immunohistochemical staining were done by 
using the avidin biotin peroxidase complex technique ${ }^{[14]}$ for caspase-3 (a rabbit polyclonal antibody, CPP32, Ab-4 $\mathrm{IgG}$ ) and for VEGF (a rabbit polyclonal Ab-1; IgG). These were purchased from Thermo Fisher Scientific; Fremont, USA. Tissue sections were counterstained with Mayer's hematoxylin.

\section{Morphometric Study}

Using Leica Qwin 500 LTD image analysis (Cambridge, UK), The following parameters were measured:

The area \% of collagen fibers in Masson's trichrome stained sections.

The area $\%$ of caspase 3 and VEGF immunoreactivity were recorded in immunostained sections.

The measurements were done in 10 random high power (x400) non overlapping fields for each section using the binary mode.

\section{Statistics}

Quantitative data were summarized as means and standard deviations and compared using analysis of variance (ANOVA) followed by post-Hoc analysis (Tukey test). $P$ values $<0.05$ were considered statistically significant. Calculations were made on statistical package of social science (SPSS) software, version 16.

\section{RESULTS}

No deaths were noticed among rats during the experiment.

The histological and immunohistochemical results of all subgroups of the control group were similar. So, they were referred to by control group (GI).

\section{I) Hematoxylin and Eosin stained sections}

Control group (G I) revealed branching anastomosing cardiac muscle fibers with acidophilic sarcoplasm, visible cross striations, intercalated discs and central oval vesicular nuclei. Flat dark nuclei of fibroblasts and normal blood capillaries were also detected (Figure 1A).

Isoproterenol treated group after 2 weeks (g IIa) showed discontinuity and degeneration of cardiac muscle fibers with increased sarcoplasmic eosinophilia and loss of cross striations. Inflammatory cellular infiltration and pyknotic nuclei were also observed (Figure 1B). After 6 weeks (g IIb), there were degenerated fibers with increased eosinophilia and areas of exudate, pyknotic nuclei, dilated congested blood vessels, extravasation of RBCs and many fibroblasts (Figure 1C).

In mangosteen treated group (G III) there were degenerated fibers with increased eosinophilia in some parts. Pyknotic nuclei, congested and dilated blood vessels, extravasation of RBC's and few inflammatory cellular infiltration were also detected. Some fibers show transverse striations, intercalated discs and oval vesicular nuclei (Figure 1D).
Mesenchymal stem cells treated group after 6 weeks (g IVb) revealed some areas of degenerated fibers among nearly normal ones. The nuclei appeared oval, central and vesicular. Few inflammatory cellular infiltration in between the muscle fibers, dilated blood vessels were also demonstrated (Figure 1E).

The combined treated group $(\mathrm{g} \mathrm{Vb})$ revealed obvious decline in the myocardial damage induced by ISO. The majority of the myocardial fibers appeared normal. Fibroblasts and few cellular infiltration were noticed (Figure1F).

\section{II) Masson's Trichrome stained sections}

Sections of control group revealed fine collagen fibers between the cardiac muscle fibers (Figure 2A). While in $\mathrm{g}$ $\mathrm{IIa}$ and $\mathrm{g} \mathrm{IIb}$, there were increased amount of irregularly arranged collagen fibers (Figures 2B \& 2C). Group III showed collagen fibers surrounding mainly blood vessels and few collagen fibers in between cardiac muscle fibers (Figure 2D). Group IVb showed few irregularly arranged collagen fibers (Figure 2E) and $\mathrm{g} \mathrm{Vb}$ showed minimal amount of collagen fibers in between cardiac muscle fibers (Figure 2F).

\section{III) Caspase-3 stained myocardial sections}

Almost -ve immunoreaction for caspase-3 was observed in GI (Figure 3A). However, g IIa revealed strong sarcoplasmic immunoreaction and $\mathrm{g}$ IIb revealed +ve immunoreaction in the sarcoplasm of many cardiac muscle fibers (Figures 3B \& 3C). Group III showed strong sarcoplasmic immunoreaction of few fibers. The rest of fibers showed moderate immunoreaction (Figure 3D). Group IVb showed sarcoplasmic immunoreaction of some cardiac muscle fibers (Figure 3E) and group $(\mathrm{g} \mathrm{Vb})$ showed immunoreaction in few cardiac muscle fibers (Figure 3F).

\section{IV) VEGF stained myocardial sections}

The control group revealed mild +ve immunoreaction in the cytoplasm of endothelial cells (Figure 4A). Group IIa revealed +ve immunoreaction of inflammatory cells and endothelial cells (Figure 4B) while g IIb and G III revealed +ve immunoreaction of endothelial cells (Figures 4C \& 4D). Group IVb and $\mathrm{g} \mathrm{Vb}$ showed +ve immunoreaction of endothelial cells lining many blood vessels (Figures 4E \& 4F).

\section{V) Quantitative Morphometric Results}

- Mean area \% of the collagen fibers in Masson's Trichrome stained sections: (Table 1, Figure 5A)

Subgroup IIb showed significant increase $(P<0.05)$ when compared to all other groups except for g IIa. There was significant decrease in G III compared to $\mathrm{g}$ IIb. Subgroup IVb displayed significant decrease as compared to g IIb. Subgroup Vb showed a decrease compared to all other groups except for GI. The decrease was statistically significant with all other groups except for $\mathrm{g} I \mathrm{Vb}$. 


\section{- Mean area\% of caspase-3 immunoreaction: (Table 1, Figure 5B)}

Subgroups IIa and g IIb revealed significant increase $(P<0.05)$ compared to $\mathrm{G} \mathrm{I}, \mathrm{g} \mathrm{IVb}$ and $\mathrm{g} \mathrm{Vb}$. Group III showed a significant decrease as compared to $\mathrm{g}$ IIa. Subgroup IVb showed a significant decrease as compared to $\mathrm{g}$ IIb and G III. Subgroup Vb revealed significant decrease as compared to all other diseased groups except GI and $\mathrm{g} I \mathrm{Vb}$.

\section{- Mean area\% of VEGF immunoreaction: (Table 1, Figure 5C)}

Subgroup IIa showed a significant increase compared to GI and a significant decrease as compared to $\mathrm{g} I V b$ and $\mathrm{g} \mathrm{Vb}$. However, g IIb revealed insignificant decrease as compared to g IIa. Subgroup III showed a significant decreased compared to $\mathrm{g} \mathrm{IVb}$ and $\mathrm{g} \mathrm{Vb}$ and insignificant increase compared to $\mathrm{g}$ IIb. Subgroups $\mathrm{IVb}$ and $\mathrm{g} \mathrm{Vb}$ revealed a significant increase as compared to all other groups, however, $\mathrm{g} \mathrm{Vb}$ was significantly increased as compared to $\mathrm{g} \mathrm{IVb}$.

\section{VI) Fluorescent Microscope Results}

Both $\mathrm{g}$ IVa and $\mathrm{gVa}$ revealed MSCs labeled with PKH26 dye (Figures 6A \& 6C) while $\mathrm{g} \mathrm{IVb}$ and $\mathrm{g} \mathrm{Vb}$ showed absence of labeled MSCs (Figures 6B and 6D).

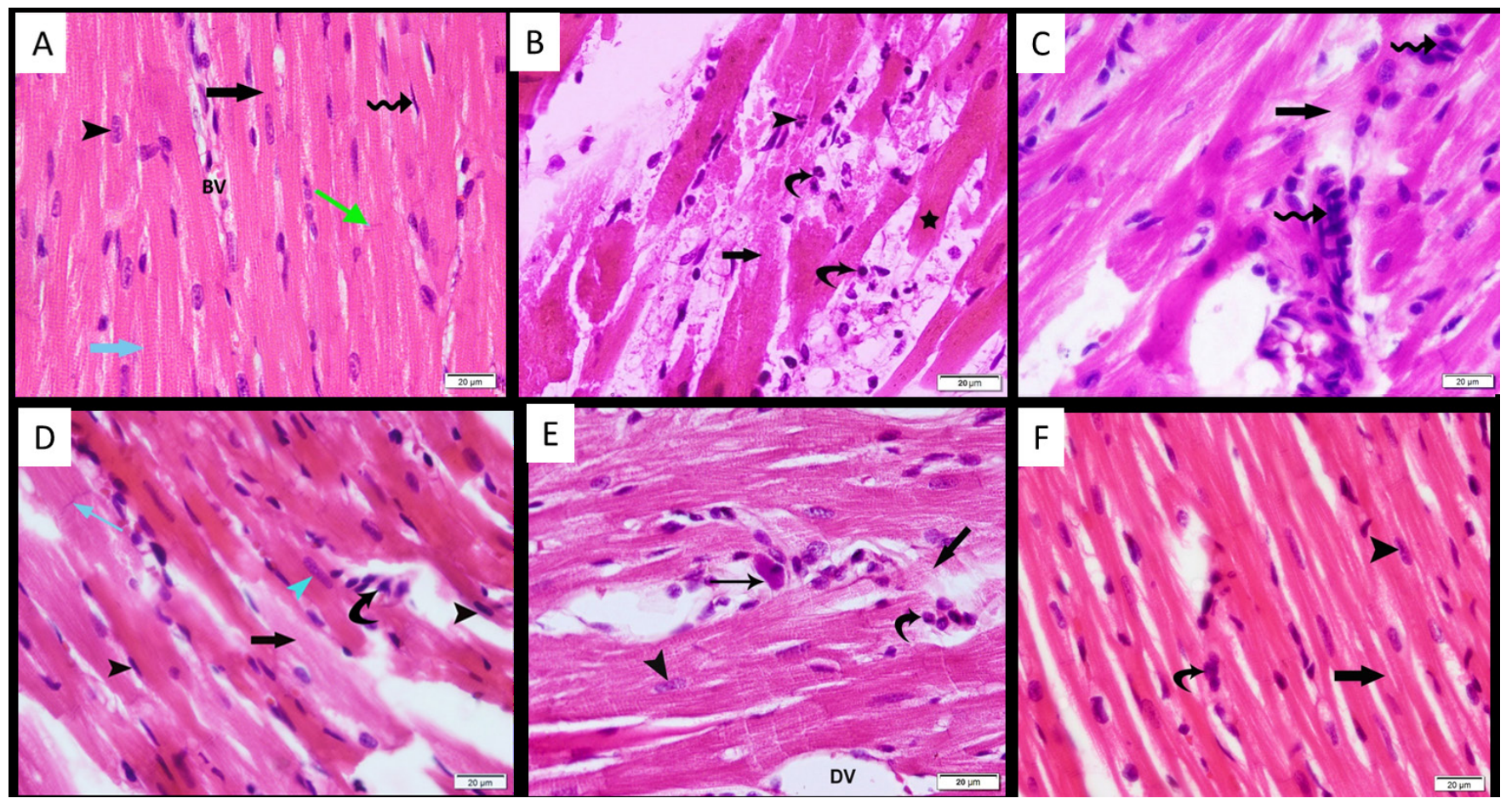

Fig. 1: Photomicrograph of H\&E stained sections in the apex of the left ventricle: A (GI = control): shows acidophilic sarcoplasm (black arrow), visible cross striations (blue arrow), Intercalated discs (green arrows) and central oval vesicular nuclei (arrowhead). There are also flat dark nuclei of fibroblasts (zigzag arrow) and blood capillaries (BV). B ( $\mathrm{g}$ IIa $=$ ISO, 2w) illustrates degenerated, disrupted and widely separated cardiac muscle fibers (black arrow) with increased sarcoplasmic eosinophilia (star). Nuclear pyknosis (arrowhead) and inflammatory cellular infiltration (curved arrows) are also seen. C ( $\mathrm{g}$ IIb $=\mathrm{ISO}$, $6 \mathrm{w}$ ) shows cardiac myocytes degeneration (black arrow) and many fibroblasts (zigzag arrows). D (G III = Mangosteen + ISO) demonstrates degenerated cardiac muscle fibers (black arrow), intercalated discs (thin blue arrow), pyknotic nuclei (black arrowheads),oval vesicular nucleus (blue arrowhead) (arrowheads) and few inflammatory cellular infiltration (curved arrow).E ( $\mathrm{g}$ IVb $=$ ISO + MSCs, 1M) shows nearly normal cardiac muscle fibers with central oval pale nuclei (arrowhead). Some areas of degenerated cardiac muscle fibers (black arrow), few inflammatory cellular infiltration (curved arrow) and dilated blood vessel are also detected (DV). Notice the presence of mast cell (thin arrow).F(g Vb = Mangosteen + ISO + MSCs, 1M) shows branching anastomosing cardiac muscle fibers (black arrow) with central, oval and vesicular nuclei (arrow head) and few cellular infiltration (curved arrow). 


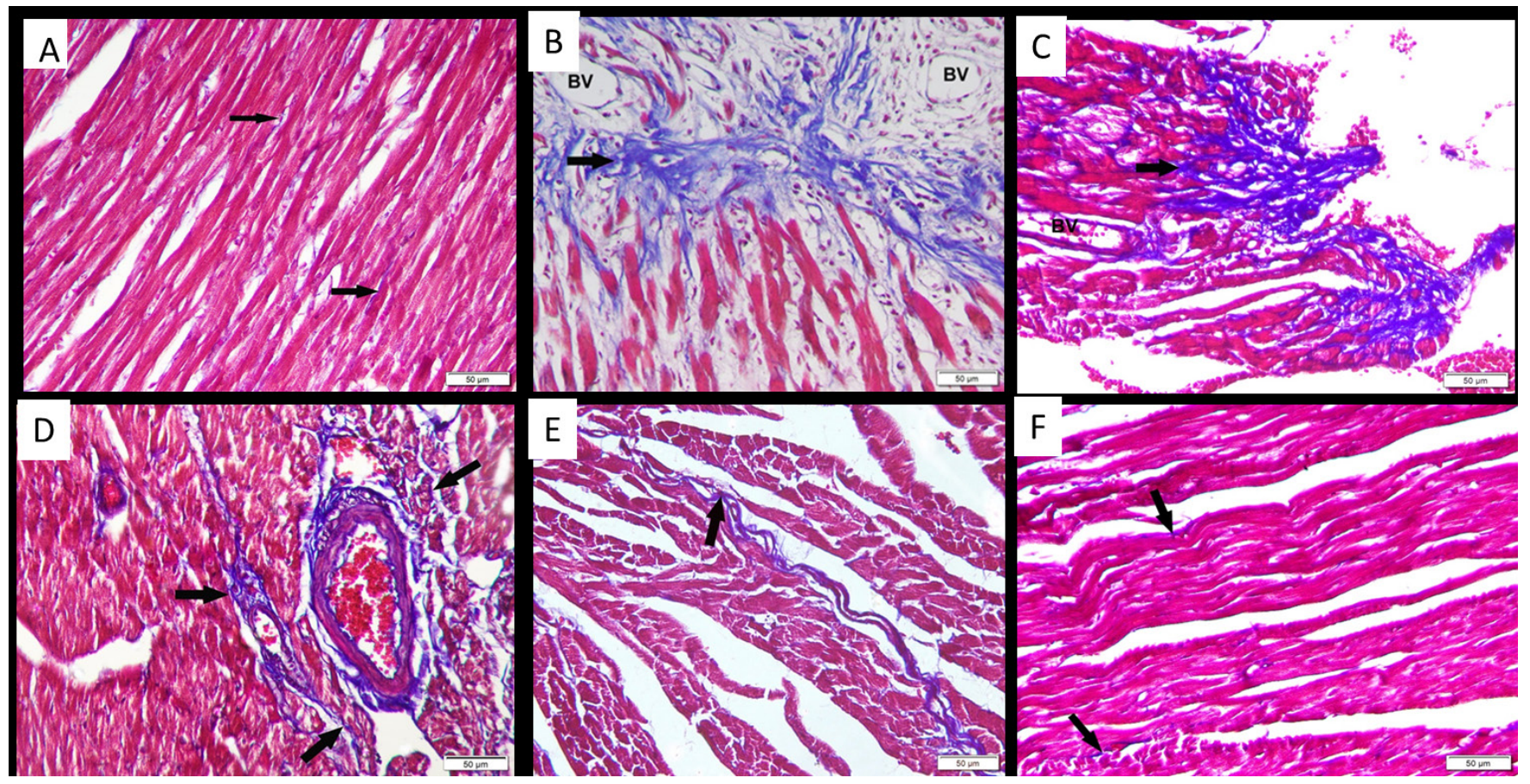

Fig. 2: Photomicrograph of Masson's Trichrome stained sections in the apex of the left ventricle: A (GI = control) shows fine collagen fibers (arrows) between the cardiac muscle fibers. B $(\mathrm{g} \mathrm{IIa}=\mathrm{ISO}, 2 \mathrm{w})$ and $\mathrm{C}(\mathrm{g} \mathrm{IIb}=\mathrm{ISO}, 6 \mathrm{w})$ demonstrate an increase in the amount of irregularly arranged collagen fibers (arrow) and dilated blood vessels (BV). D (G III = Mangosteen + ISO) illustrates collagen fibers surrounding mainly blood vessels and few collagen fibers (arrows) in between cardiac muscle fibers. $\mathrm{E}(\mathrm{g} \mathrm{IVb}=\mathrm{ISO}+\mathrm{MSCs}, 1 \mathrm{M}$ ) shows few irregularly arranged collagen fibers (arrow). F ( $\mathrm{g} \mathrm{Vb}=$ mangosteen $+\mathrm{ISO}+\mathrm{MSCs}$, $1 \mathrm{M})$ shows minimal amount of collagen fibers (arrows).

(Masson's Trichrome: A,B,C,D,E\&F X200)

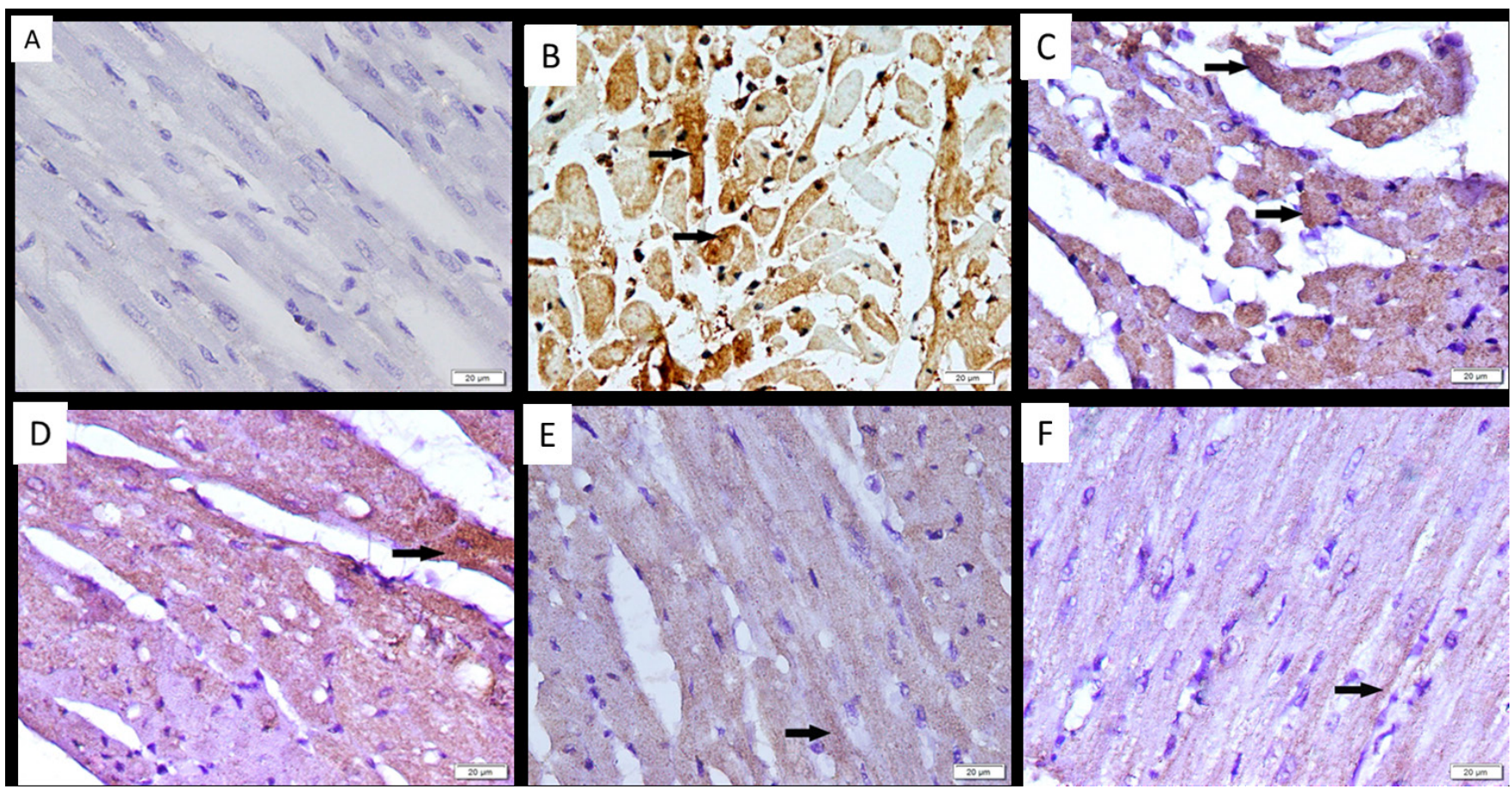

Fig. 3: Photomicrograph of caspase-3 (space between of and caspase-3) immunostained sections in the apex of the left ventricle: A (GI = control) shows negative immunoreactivity in the sarcoplasm of cardiac muscle fibers. B ( $\mathrm{g}$ IIa $=\mathrm{ISO}, 2 \mathrm{w}$ ) and $\mathrm{C}$ ( $\mathrm{g} \mathrm{IIb}=\mathrm{ISO}$, 6w) demonstrate positive immunoreactivity in the sarcoplasm of many muscle fibers (arrows).D( $\mathrm{g} \mathrm{III}=$ mangosteen $+\mathrm{ISO}$ ) illustrats strong positive immunoreactivity in few muscle fibers (arrow), the rest of fibers showed reduced immunoreactivity. $\mathrm{E}(\mathrm{g}$ IVb $=\mathrm{ISO}+\mathrm{MSCs}, 1 \mathrm{M})$ shows reduced immunoreactivity of some muscle fibers $(\operatorname{arrow}) . \mathrm{F}(\mathrm{g} \mathrm{Vb}=$ mangosteen + ISO + MSCs, 1M) demonstrates slight immunoreactivity in few muscle fibers (arrow).

(Anti-caspase-3 immunostaining: A,B,C,D,E\&F X 400) 


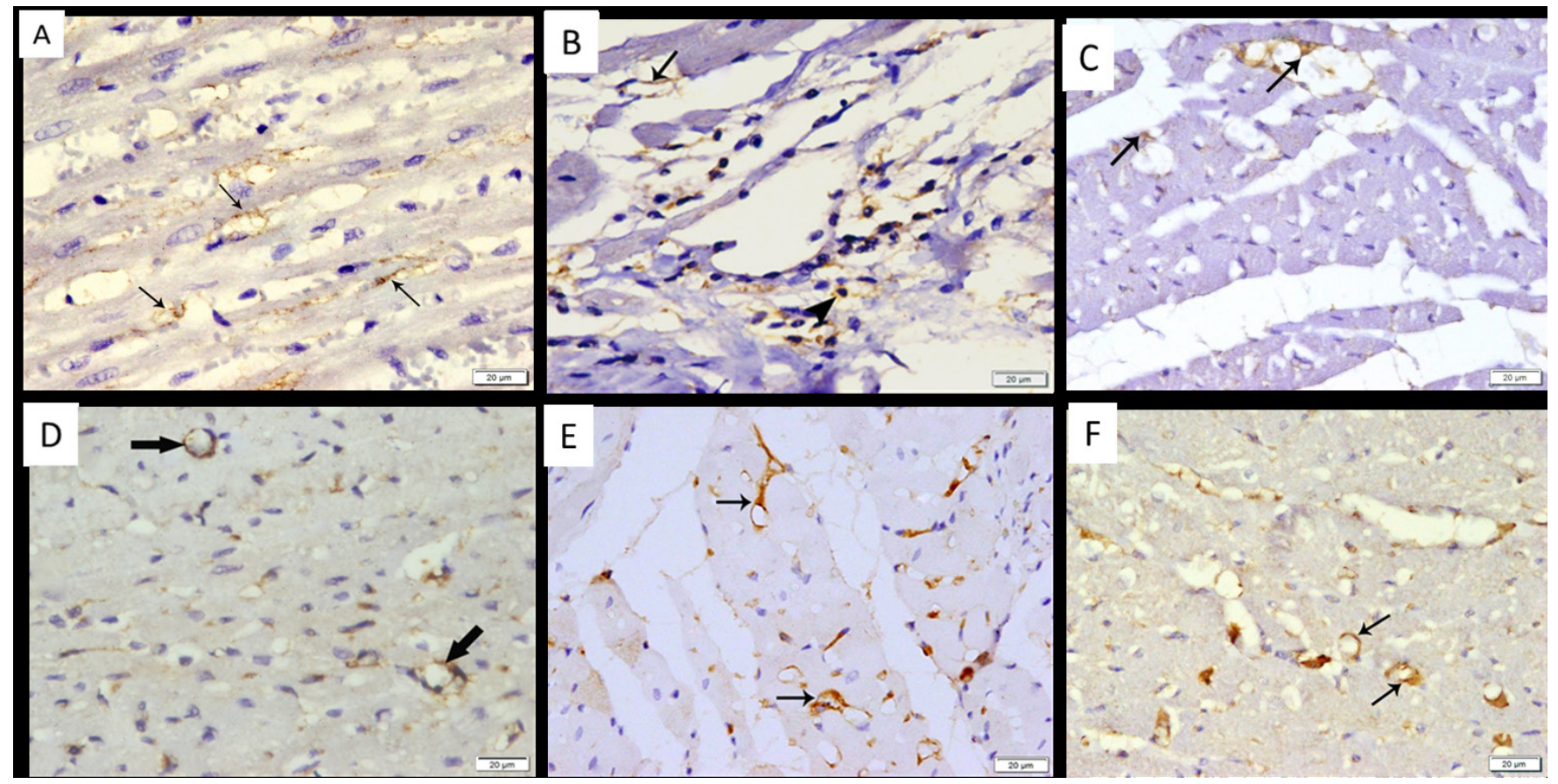

Fig. 4: Photomicrograph of VEGF immunostained sections in the apex of the left ventricle: A (GI = control) shows mild positive immunoreaction in the cytoplasm of endothelial cells lining the blood vessels (arrows). B ( $\mathrm{g}$ IIa $=\mathrm{ISO}, 2 \mathrm{w}$ ) demonstrates positive immunoreaction in the inflammatory cells (arrow head) and the endothelial cells (arrow). There is positive immunoreaction in the endothelial cells lining the blood vessels in C $(\mathrm{g} I \mathrm{Il}=\mathrm{ISO}, 6 \mathrm{w})$ and $\mathrm{D}(\mathrm{G} \mathrm{III}=$ mangosteen + ISO) and in many blood vessels in $\mathrm{E}(\mathrm{g} \mathrm{IVb}=\mathrm{ISO}+\mathrm{MSCs}, 1 \mathrm{M})$ and F ( $\mathrm{g} \mathrm{Vb}=$ mangosteen + ISO + MSCs, 1M) (arrows).

(Anti-VEGF immunostaining: A,B,C,D,E\&F X 400)
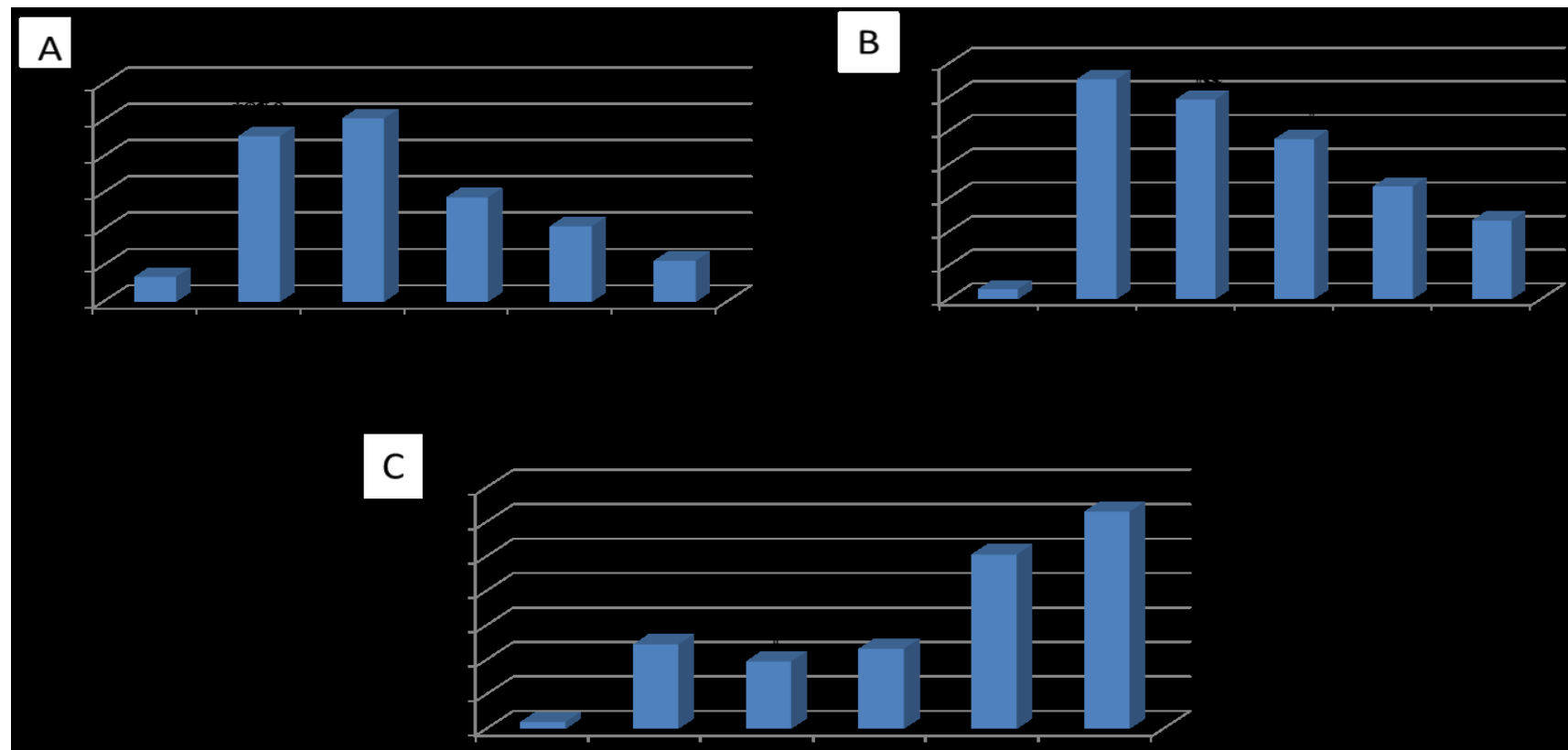

Fig. 5: Histogram comparing (A): the mean values of area $\%$ of collagen fibers in the control and experimental groups, (B): the mean values of area $\%$ of caspase $3+v e$ cells in the control and experimental groups, (C): the mean values of area \% of VEGF+ve cells in the control and experimental groups.

*: significant $\mathrm{P}$ as compared to GI $(P<0.05)$.

+ : significant $\mathrm{P}$ as compared to gIIa $(P<0.05)$.

\#: significant $\mathrm{P}$ as compared to gIIb $(P<0.05)$.

$\$$ : significant $\mathrm{P}$ as compared to $\mathrm{g}$ III $(P<0.05)$.

ๆ: significant $\mathrm{P}$ as compared to gIVb $(P<0.05)$.

$\&$ : significant $\mathrm{P}$ as compared to $\mathrm{gVb}(P<0.05)$. 


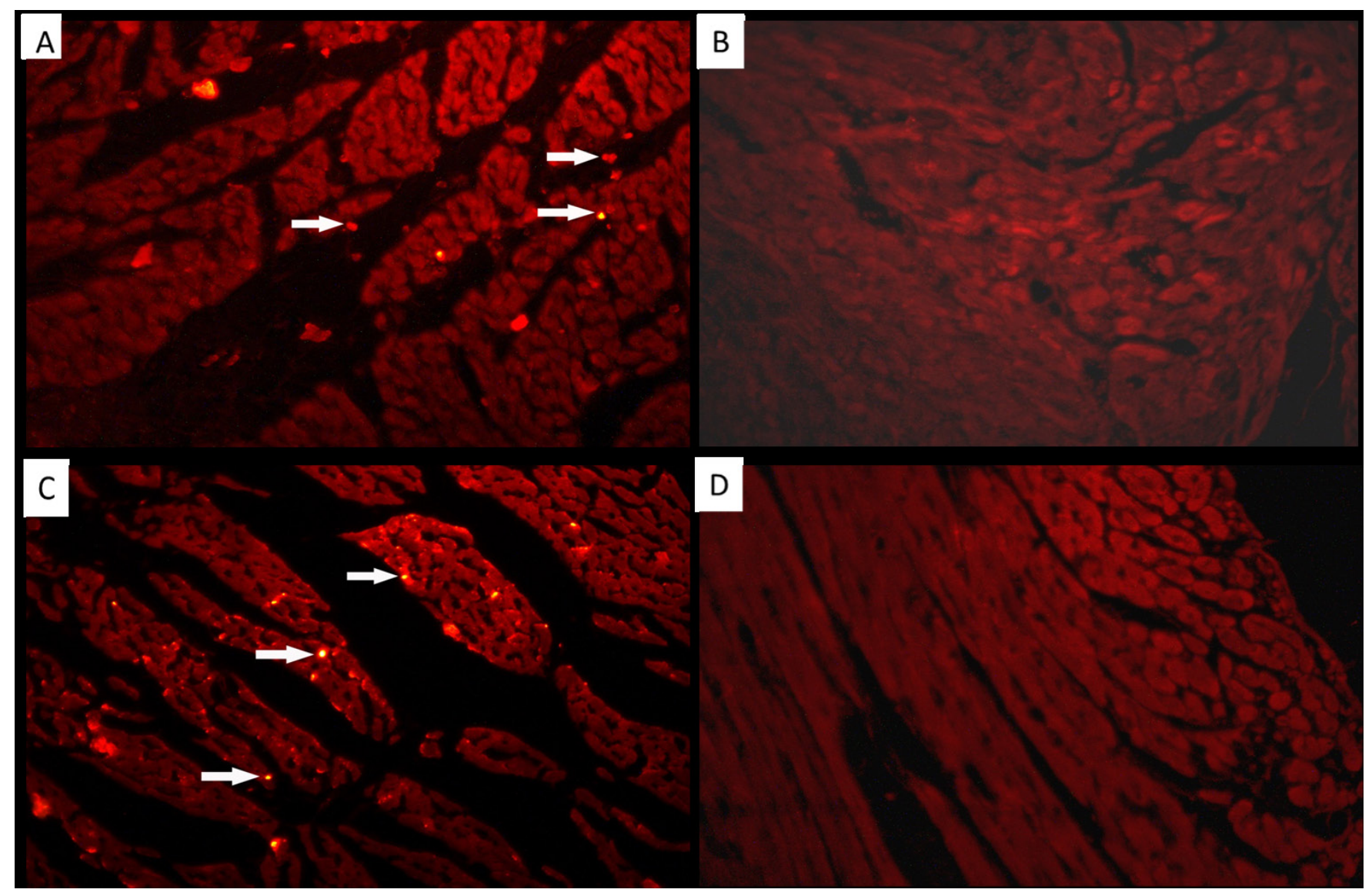

Fig. 6: Fluorescent photomicrograph of a section in the apex of the left ventricle: A ( $\mathrm{g}$ IVa $=\mathrm{ISO}+\mathrm{MSCs}, 6 \mathrm{~d})$ and $\mathrm{C}(\mathrm{g}$ Va $=$ mangosteen $+\mathrm{ISO}+\mathrm{MSCs}$, 6d) show MSCs labeled with PKH26 dye (arrows). However B (g IVb = ISO + MSCs, 1M) and D (g Vb = mangosteen + ISO + MSCs, 1M) show absence of labeled MSCs.

(PKH26 dye, x200)

Table 1: The mean values of the area $\%$ of collagen fibers, area $\%$ of caspase 3 and area $\%$ of VEGF $( \pm S D)$

\begin{tabular}{|c|c|c|c|}
\hline Groups & Mean area $\%$ of collagen fibers \pm SD & Mean area $\%$ of caspase $-3 \pm \mathrm{SD}$ & Mean area $\%$ of $\mathrm{VEGF} \pm \mathrm{SD}$ \\
\hline G I & $0.67( \pm 0.14)^{+* \pm \$ \Phi}$ & $0.29( \pm 0.09)^{++\$ 9 \uparrow \& \mathbb{C}}$ & $0.18( \pm 0.05)^{++\$ 99 \mathbb{C}}$ \\
\hline G II a & $4.55( \pm 0.88)^{+\$ 9 \&}$ & $6.52( \pm 0.94)^{*}$ sథ\& & $2.43( \pm 0.47)^{*}$ \\
\hline G II b & $5.04( \pm 0.79)^{+59 \&}$ & $5.92( \pm 1.12)^{* \pi \in c}$ & $1.94( \pm 0.62)^{m+\infty}$ \\
\hline G III & $2.79( \pm 0.54)^{*+\# \notin \varepsilon}$ & $4.74( \pm 0.77)^{*+\uparrow \&}$ & $2.31( \pm 0.63)^{* \pi[e}$ \\
\hline G IV b & $2.07( \pm 0.50)^{* * \#}$ & $3.34( \pm 0.83)^{*+\# \mathrm{~S}}$ & $5.05( \pm 1.07)^{*+\# \& \&}$ \\
\hline $\mathrm{GVb}$ & $1.12( \pm 0.36)^{\text {+\#S }}$ & $2.33( \pm 0.75)^{*+\# \mathrm{H}}$ & $6.29( \pm 1.08)^{*+\#+\$ \Phi}$ \\
\hline
\end{tabular}

*: significant $\mathrm{P}$ as compared to GI $(P<0.05)$.

+ : significant $\mathrm{P}$ as compared to gIIa $(P<0.05)$.

\#: significant $\mathrm{P}$ as compared to gIIb $(P<0.05)$.

$\$$ : significant $\mathrm{P}$ as compared to $\mathrm{g}$ III $(P<0.05)$.

I: significant $\mathrm{P}$ as compared to $\mathrm{gIVb}(P<0.05)$.

\&: significant $\mathrm{P}$ as compared to $\mathrm{gVb}(P<0.05)$. 


\section{DISCUSSION}

In the present study, ISO was used as a simple and non-invasive method to induce MI. It induces maximum necrosis in the left ventricle, interventricular septum and the apex of the heart ${ }^{[16]}$. For that, in this study all the cardiac sections were taken from the apex of the left ventricle.

Isoproterenol administration revealed several histological alterations. After 2 weeks (g IIa), most of the muscle fibers exhibited discontinuity and degeneration with increased sarcoplasmic eosinophilia and loss of cross striations. They appeared thin disrupted and widely separated with inflammatory cellular infiltration. The nuclei appeared pyknotic and marginated. These changes could be due to ISO-induced cardiotoxicity through induction of oxidative stress.

Similar changes in rats receiving ISO were reported by other authors in the form of fragmentation of cardiac fibers, necrosis, hyalinization with increased eosinophilia of cardiomyocytes, inflammatory cellular infiltration and edema $^{[17]}$.

Isoproterenol leads to calcium overload that causes decomposition of membrane phospholipids due to activation of the phospholipase ${ }^{[18]}$. It induces a robust decrease in the antioxidant enzymes that play a vital role in free radical scavenger ${ }^{[19]}$. It also results in enhancement of lipid peroxidation that affects the efficacy of cardiomyocyte and lowers the blood supply to the heart ${ }^{[20]}$.

In the present study, the cardiomyocytes showed pyknotic and marginated nuclei which could be attributed to apoptosis as reported by other studies ${ }^{[21]}$. A possible explanation for this could be that apoptosis and necrosis share common biochemical pathways in the early stages of the process. Apoptosis could even work as a precursor of secondary necrosis.

After acute myocardial infarction, for a rat, myocardial necrosis appears in infarct zone and scar forms, and meanwhile, apoptosis of myocardial cells happens in infarct size, scar area, infarction border zone and noninfarcted zone ${ }^{[22]}$.

The wide separation of degenerated fibers and inflammatory cellular infilteration seen in the present study could be attributed to oedema and inflammation. These findings were explained by other authors who noticed that after ISO administration, the myocardial water content increases with development of oedema in intramuscular spaces and accumulation of mucopolysaccharides in extensive necrotic changes ${ }^{[16]}$.

A previous study suggested that monocytes, neutrophil and macrophages infiltration occurred in failing myocardium. Inflammatory cells are generally contributed to extracellular matrix (ECM) deposition in tissues and initiates fibrosis ${ }^{[23]}$.

Isoproterenol group after 6 weeks (g IIb) revealed many areas of degenerated cardiac muscle fibers with increased eosinophilia in some myofibers. In some areas, wide separation of the cardiac muscle fibers and an area of exudate were noticed. Pyknotic nuclei, dilated congested blood vessels and extravasation of RBCs were also observed. Many fibroblasts could be seen in between cardiomyocytes.

The previous findings coincide with that found in a study that reported the presence of nuclear pyknosis and karyolysis as well as vacuolization and hyper eosinophilia after 6 weeks of induced MI by left coronary artery occlusion. They also revealed that after 6 weeks, an ongoing acute inflammatory process was still present ${ }^{[24]}$.

Fibroblasts observed in the current study could be explained by the increased fibrosis process to replace areas of degenerated cardiac muscle fibers by collagen fibers. Fibrosis has a chief role in repairing the damaged myo $\neg$ cardium, but excess and deregulated fibrosis may contribute to pathological cardiac remodeling ${ }^{[25]}$.

Extravasation of RBC's in this study could be explained by the occurrence of coagulative necrosis that causes microvascular injury; endothelial cell detachment; vascular leakage and tissue edema ${ }^{[26]}$.

The mangosteen treated group illustrated apparent decrease in inflammatory cellular infiltration and better muscle architecture as compared to the ISO group. These findings suggest a partial improvement in the cardiac muscle fibers. However, these findings were less than expected that might be due to low dose of mangosteen given in the current study.

The ability of mangosteen to reduce the effect of ISO could be attributed to its effect as potent antioxidant and anti-inflammatory as in other organs ${ }^{[27]}$.

Mangosteen peels contain compounds that are useful as antioxidants and are pharmacologically active like flavonoid, $\alpha$-mangostin, and tannin ${ }^{[28]}$ similar to the components of the mangosteen drug used in this study.

An author postulated that $\alpha$-mangostin diminishes the infarcted area, prevents the decrease in cardiac ATP and phosphocreatine levels and reduces the oxidative stress $^{[29]}$. In another work, a significant decrease in the activities of transaminases, lactate dehydrogenase and creatine phosphokinase in the serum of ISO treated rats that were pretreated with $\alpha$-mangostin were observed ${ }^{[30]}$. Pretreatment with flavonoid and $\alpha$-mangostin significantly decrease cardiac malondialdehyde (MDA) and increase reduced glutathione (GSH) content which can be attributed to potent antioxidant activity of flavonoid ${ }^{[16]}$.

The decreased inflammatory cellular infiltration in mangosteen treatmented group could be explained by another author ${ }^{[31]}$ who stated that xanthones detected inside the mangosteen peel inhibit the production of the cyclooxygenase-2 (COX-2) enzyme (the main cause of inflammation), nitric oxide (NO) and prostaglandin 2 (PGE2). Other study displayed that $\alpha$ - Mangostin 
attenuated the expression of inflammatory genes in human adipocytes stimulated with lipopolysaccharide (LPS) ${ }^{[32]}$. Diminished ROS generation could be also attributed to the reduction of the inflammatory procedure ${ }^{[24]}$.

In the current study, fluorescent photomicrographs in MSCs treated groups revealed the presence of MSCs labeled with PKH26 dye in groups (g IVa and g Va,). This finding indicates homing of the MSCs. Homing process of stem cells could be related to the beginning of the inflammatory process and cytokines released ${ }^{[33]}$. On the other hand, $\mathrm{g} \mathrm{IVb}$ and $\mathrm{g} \mathrm{Vb}$ revealed absence of labeled MSCs which could be due to differentiation of the stem cells after one month.

In the present study, mesenchymal stem cells treated group after one month ( $\mathrm{g} \mathrm{IVb}$ ) showed apparent improvement of cardiac muscle fibers with normal appearance of the nuclei as compared to $\mathrm{g} I \mathrm{Ib}$. There were small areas of degeneration and lysis of cardiac muscle fibers among nearly normal fibers. The nuclei appeared normal. Few inflammatory cellular infiltration, dilated blood vessels and mast cells were also demonstrated.

The number of necrotic cardiomyocytes was markedly decreased after treatment with MSCs after 3 weeks was also reported by earlier studies ${ }^{[15]}$ and they observed a reduction of mononuclear cellular infiltration and hemorrhage ${ }^{[15]}$. However, other studies reported a negative or no obvious functional benefits between MSCs-treated and diseased hearts ${ }^{[34]}$. Reasons for the discrepancies include all aspects of cell therapy such as different levels of cardiac impairment, animal age, variations in the time, and methods of cell delivery and the number of cells injected ${ }^{[35]}$.

Bone marrow derived MSCs had been used in this study as they were utilized to treat patients with acute myocardial infarction (AMI) and heart failure (HF) in clinical trials due to their safety and efficacy ${ }^{[36]}$.

In the current study, MSCs were delivered by intramyocardial injection because it provides better cell retention. Intravenous administration of MSCs had been tried but there were very poor retention in the cardiac tissues. It was proved that the majority of IV administered MSCs were lodged in the lung despite the presence or absence of lung injury ${ }^{[37]}$.

The mechanisms of functional and structural improvement of cardiac muscle after MSCs treatment remain unclear. It was originally assumed that MSCs differentiated into multiple cardiac cell types including cardiomyocytes, vascular endothelial cells, and vascular smooth muscle cells ${ }^{[38]}$.

On the other hand, other studies did not demonstrate this remarkable differentiation capacity of MSCs and most of IV injected cells are trapped in the lung rather than in the heart. Moreover, the supernatant of MSC cultures reportedly improves cardiac function ${ }^{[39]}$.

These results suggested that MSCs improved cardiac function via the secretion of paracrine factors rather than via the direct differentiation of MSCs into cardiac cell types. The paracrine mechanisms include antiapoptotic, proangiogenic and antifibrotic effects ${ }^{[40]}$.

However, another mechanism was reported which is that exogenous stem cells may also stimulate proliferation of endogenous cardiac stem cells through neovascularization or paracrine signaling ${ }^{[41]}$.

The few inflammatory cellular infiltration observed in this group could be clarified by another study that reported the MSCs affect both pro and anti-inflammatory processes and could be utilized to diminish inflammatory injury in $\mathrm{MI}^{[42]}$.

In combined treated group after 1 month $(\mathrm{g} \mathrm{Vb})$ there was an obvious decline in the myocardial damage. The majority of the myocardial fibers appeared branching and anastomosing with central, oval and vesicular nuclei. Fibroblasts and few cellular infiltration were also noticed.

This improvement could be attributed to the synergistic effect of both the anti-oxidant, anti-inflammatory action of mangosteen and the positive effect of MSCs on the infarcted tissue.

Previous studies indicated that the low survival rate of implanted MSCs is mainly due to the hostile microenvironment in injured tissue, and ROS burst is the major risk factor. This result reflects the need to find new methods to enhance the survival of MSC in oxidative stress injury. In addition, large amounts of MSC are needed due to the poor survival in the inflammatory environment of $\mathrm{MI}^{[1]}$.

For that, the anti-oxidant and anti- inflammatory effects of mangosteen could improve the environment surrounding the MSCs and lead to better survival of them. Furthermore, mangosteen could cause enhancement of MSCs differentiation as it was reported by earlier study that $\alpha$-mangostin promotes myoblast differentiation of $\mathrm{C}_{2} \mathrm{C}_{12}$ cells which are murine myoblasts derived from satellite cells ${ }^{[43]}$.

In Masson's Trichrome stained sections of control group, there were fine collagen fibers between the cardiac muscle fibers. Isoproterenol treated group revealed increase in the amount of irregularly arranged collagen fibers in between disrupted fibers. This increase was statistically significant with the control group. There was a moderate increase in the amount of collagen fibers in $\mathrm{g}$ IIb as compared to $\mathrm{g}$ IIa.

These findings coincide with another work that detected excessive fibrous tissue deposition after one week from ISO administration ${ }^{[23]}$. However, a different study revealed minimal increase in collagen fibers in between the cardiac myocytes after one week of administration of ISO compared to after four weeks ${ }^{[15]}$.

It was stated that damaged zones of the myocardium were progressively replaced by highly vascularized granulation tissue, which progressively becomes less vascularized and more fibrous. They added that. Scarring 
is well advanced, mostly, by the end of the fourth week ${ }^{[26]}$.

In mangosteen treated group (G III), the collagen fibers surrounded mainly blood vessels and few collagen fibers in between cardiac muscle fibers. There was significant decrease in the area percent of collagen fibers in of G III compared to $\mathrm{g} \mathrm{IIb}$.

In a study using $\alpha$-mangostin to find its effect on liver fibrosis in rats, a significant reduction of the liver fibrosis scores was detected ${ }^{[44]}$. They suggested that the mechanism of action may involve the anti-inflammatory activity of $\alpha$-mangostin as liver fibrosis is always preceded by inflammation and oxidative stress ${ }^{[44]}$.

In MSCs treated group (g IV), few irregularly arranged collagen fibers running in between cardiac muscle fibers were seen with significant decrease in the mean area $\%$ of collagen fibers as compared to $\mathrm{g}$ IIb. This finding could be attributed to the antifibrotic effect of MSCs.

Preclinical studies suggested that MSCs have a promising level of efficacy in the treatment of fibrosis due to the immunomodulatory and trophic properties of them ${ }^{[35]}$. It was suggested that MSCs effect seemed to be due to immune modulation, mediated differentiation of various cells into myofibroblasts, and matrix remodeling ${ }^{[45]}$.

Minimal collagen fibers were detected in combined group $(\mathrm{g} \mathrm{Vb})$. There was significant decrease in mean area percent of collagen fibers as compared to $\mathrm{g} \mathrm{IIb}$.

These findings suggest that myocardial fibrosis can be markedly reduced by the combined treatment. The therapeutic benefit of combined treatment could be due to the direct inhibitory action of myocardial fibrosis by both mangosteen and MSCs transplantation.

The anti-caspase- 3 antibody stained sections in control group revealed negative immunoreaction in the sarcoplasm of cardiomyocytes. The statistical analysis of the mean area \% of caspase-3 immunoreaction showed minimal amount of apoptosis in normal heart. However, there was significant increase in the mean area percent of caspase-3 immunoreaction in the infarcted group (g IIa and g IIb) as compared to control group. There was insignificant increase of the mean area percent of the caspase- 3 immunoreaction of $g$ IIa compared to $g$ IIb.

The previous mentioned findings were in line with former study that reported apoptosis after 5 weeks and was less than apoptosis after 10 days in MI induced by the left coronary artery ligation in rats ${ }^{[35]}$. Another work stated that MI increases the in situ ROS in both infarcted and noninfarcted areas after 6 weeks. Continuous hypoxia in the non-infarcted area is a major determinant of the rates of cell death ${ }^{[24]}$.

It was demonstrated that administration of ISO significantly increased the activity of caspase- 3 and DNA damage ${ }^{[46]}$. Clinical studies have demonstrated that adrenergic blockers significantly improve cardiac function and reduce cardiac apoptosis in patients with $\mathrm{HF}^{[47]}$.
In Mangosteen treated group, there was a significant decrease in the mean area percent of caspase-3 immunoreaction as compared to g IIa. This decrease could be due to decreased oxidative stress by the antioxidant effect of mangosteen.

Fang et al., (2016) ${ }^{[48]}$ observed that $\alpha$-mangostin significantly inhibited light-induced degeneration of photoreceptors and $\mathrm{H} 2 \mathrm{O} 2$-induced apoptosis of retinal pigment epithelial (RPE) cells. They also found the effective anti-apoptotic activity of $\alpha$-mangostin through modulating caspase pathway in response to oxidative stress in vitro.

On the other hand, g IVb showed immunoreaction in the cytoplasm of some cardiac muscle fibers. An apparent decrease in the caspase- 3 immunoreaction was noticed as compared to $\mathrm{g}$ IIb that was confirmed by the statistical analysis of the mean area \% of caspase- 3 immunoreaction.

These results were in line with other studies that reported the attenuation of cell apoptosis in the periinfarcted regions after MSCs transplantation (1 \& 35). It was suggested that the inhibition of apoptosis due to cytokines released from transplanted stem cells and increased Bcl-2 and its receptor ${ }^{[49]}$.

The anti-apoptotic action was more obvious in $\mathrm{g} \mathrm{Vb}$ suggesting that mangosteen and MSC may have synergistic effect to improve cardiac injury after MI. This could be due to the enhancement of MSCs anti-apoptotic effect by mangosteen.

Angiogenesis is a serious part of tissue repair, and VEGF is a strong growth factor involved in this process ${ }^{[50]}$. For that immunostaining using anti-VEGF antibody was done in all groups. There was a mild positive immunoreaction in the cytoplasm of endothelial cells lining the blood vessels in the control group. However, g IIa revealed increased immunoreaction for VEGF in the cytoplasm of inflammatory cells and the cytoplasm of endothelial cells lining the blood vessels. These findings could be explained by the increased number of the inflammatory cells after two weeks (g IIa).

It was found that activated $\mathrm{T}$ cells produce VEGF and also might deliver an angiogenic factors to sites of injury to stimulate healing ${ }^{[51]}$.

While after four weeks, $g$ IIb, the immunoreaction of VEGF was decreased and this could be due to decreased inflammatory cells but significantly increased compared to control group. The increased immunoreaction of VEGF in $\mathrm{g}$ IIb could be due to presence of hypoxia that stimulates VEGF production for neovascularization as explained by other study ${ }^{[52]}$. In addition, the angiogenesis enhanced by VEGF leads to amelioration of the hypoxic condition in the non-infarcted areas $^{[24]}$.

In mangosteen treated group, there was increase in VEGF immunoreaction but insignificant statistically compared to $\mathrm{g}$ IIb. This increase could be explained by 
a work that studied the effect of mangosteen on gastric ulcers. They reported an increase of VEGF and CD-31 that could accelerate angiogenesis and so healing of the gastric ulcers. They stated that this could be due to the antioxidant effect of mangosteen that might bind. with radical superoxide and accelerate release of free $\mathrm{NO}$ which caused increase of VEGF and CD-31 expression ${ }^{[53]}$.

In MSCs treated group (g IVb), many blood capillaries with positive immunoactivity in their endothelial cells were seen. The mean area percent of VEGF immunoreaction was significantly increased as compared to g IIb. This could be due to neovascularization as many blood capillaries were detected in myocardial sections of this group.

Rapid vascularization is the basis of the clinical outcomes in MSCs therapies ${ }^{[54]}$. Many studies proved that the paracrine effect of MSCs increases the VEGF and angiogenesis. One of them showed that after administration of MSCs intramyocardially in MI, there was significantly elevated VEGF. Expression level accompanied by increased vascular density and regional blood flow in the infarct zone ${ }^{[55]}$. Another one demonstrated a significant increase in the number of capillaries compared to control group after 4 weeks from MSCs administration ${ }^{[35]}$.

Of particular interest, an observation in Cai et al., $(2016)^{[56]}$ study revealed that inhibition of VEGF causes restriction in the protective effects of BM-MSCs on the treatment of ISO-induced myocardial hypertrophy.

Sections of $\mathrm{g} \mathrm{Vb}$ revealed marked increase in the VEGF immunoreaction. This finding indicates that the effect of MSCs in angiogenesis was enhanced by administration of mangosteen. Moreover, mangosteen can provide a better environment for the implanted MSCs besides its effect as anti-inflammatory and anti-oxidant function.

\section{CONCLUSION}

MSCs administration reduced the myocardial damage induced by ISO through its anti-apoptotic, anti-fibrotic and angiogenic effects. Mangosteen as an antioxidant and antiinflammatory could improve the environment surrounding the MSCs and lead to better survival of MSCs. Mangosteen could exerts a synergistic effect with MSCs against ISOinduced MI.

\section{CONFILICTS OF INTEREST}

There are no Confilicts of Interest.

\section{REFERENCES}

1. Meng $\mathrm{X}$, Li J, Yu M, Yang J, Zheng M, Zhang J, Sun C, Liang $\mathrm{H}$ and Liu L:Transplantation of mesenchymal stem cells overexpressing IL10 attenuates cardiac impairments in rats with myocardial infarction in J Cell Physiol. (2018) 233(1): 587-595.

2. Mikaelian I, Coluccio D, Morgan K T, Johnson T, Ryan A L, Rasmussen E, Nicklaus R, Kanwal C, Hilton H, Frank K, Fritzky L, Wheeldon E B: Temporal gene expression profiling indicates early up-regulation of interleukin-6 in isoproterenolinduced myocardial necrosis in rat in Toxicol Pathol. (2008) 36(2):256-64.

3. Shiota M, Heike T, Haruyama M, Baba S, Tsuchiya A, Fujino H, Kobayashi H, Kato T, Umeda K, Yoshimoto M, Nakahata T: Isolation and characterization of bone marrow-derived mesenchymal progenitor cells with myogenic and neuronal properties in Exp Cell Res. (2007) 313: 1008-1023.

4. Suzuki E, Fujita D, Takahashi M, Oba S and Nishimatsu H: Stem cell-derived exosomes as a therapeutic tool for cardiovascular disease in World J Stem Cells.(2016) 8(9): 297-305.

5. Chin YW and Kinghorn AD: Structural Characterization, Biological Effects, and Synthetic Studies on Xanthones from Mangosteen (Garciniamangostana), a Popular Botanical Dietary Supplement in Mini Rev Org Chem.(2008) 5(4):355-364.

6. Paget GE and Barnes JM: Toxicity tests in evaluation of drug activities pharmacometries, vol.1 toxicity tests, (Laurence, D. R. and Bacharach, A. L). Academic Press, London and New York.(1964) chap.6, pp:135-151.

7. Zhang J, Knapton A, Lipshultz S E, Weaver J L, and Herman E H: Isoproterenol-induced cardiotoxicity in sprague-dawley rats: correlation of reversible and irreversible myocardial injury with release of cardiac troponin $\mathrm{T}$ and roles of iNOS in myocardial injury in Toxicol Pathol. (2008) 36(2): 277-278.

8. Karpov AA, Uspenskaya YK, Minasian SM, Puzanov MV, Dmitrieva RI, Bilibina AA, Anisimov SV and Galagudza MM: The effect of bone marrowand adipose tissue-derived mesenchymal stem cell transplantation on myocardial remodelling in the rat model of ischaemic heart failure in Int J Exp Pathol. (2013) 94(3):169-177.

9. Alhadlaq A and Mao JJ: Mesenchymal stem cells isolation and therapeutics in Stem Cells Dev. (2004) 13: 436-448.

10. Feng SW, Yao XL, Li Z, Liu TY, Huang W and Zhang C: In vitro bromodeoxyuridine labeling of rat bone marrow-derived mesenchymal stem cells (English abstract) inDi Yi Jun Yi Da Xue Xue Bao. (2005) 25: 184-186.

11. Abdel Aziz MT, Wassef MA, Rashed LA, Mhfouz S, Omar N and Elsebaie MM: Mesenchymal Stem Cells Therapy in Acute Renal Failure: Possible Role of Hepatocyte Growth Factor in J. Stem Cell Res Ther. (2011) 1: 1-7.

12. Rafsanjani FN, Adeli S, Ardakani ZV, Ardakani JV, Ghotbi P: Effects of diabetes mellitus on gastric 
motility in rats in Pak J Physiol. (2009) 5(1): 23-26.

13. Kiernan JK: Histological and Histochemical methods: Theory and practice. $3^{\text {rd }}$ ed., Arnold Publisher, London, New York, and New Delhy. (2001) pp:111-162.

14. Bancroft JD and Gamble M: Theory and Practice of Histological Techniques. $7^{\text {th }}$ edition, John Bancroft, Churchill Livingstone, Edinburgh, London, Madrid, New York and Tokyo.(2008) pp: 147-150.

15. Abdelhadi Z, Naeim M, El-Wazir Y, Ibrahim M and Hosny S: Histological study on the effect of transplanted human umbilical cord blood CD34+ stem cells on albino rats subjected to myocardial infarction in Journal of African Association of Physiological Sciences.(2015) 3(1): 49-57.

16. Savsani H, Shah H, Patel $K$ and Gandhi $\mathrm{T}$ :Cardioprotective effect of flavonoids rich fraction of Premnamucronata on isoproterenolinduced myocardial infarction in wistar rats in Int J Phytopharmaco.(2014) 5(2): 95-108.

17. Abood AM and Elshal MF: VDR stimulation improves outcome of isoprenaline-induced myocardial infarction in rats via down-regulation of cardiac inos gene expression in Biomed Res. (2015) 26(4): 755-764.

18. Hu W S, Lin Y M, Ho T J, Chen R J, Li Y H, Tsai F J, Tsai C H, Day C H, Chen T S and Huang C $\mathrm{Y}: \mathrm{Ge} \neg$ nistein suppresses the isoproterenol-treated H9c2 cardiomyoblast cell apoptosis associat $\neg$ ed with P-38, Erk1/2, JNK, and NF kappa B $\operatorname{sig} \neg$ naling protein activation in Am J Chin Med. (2013) 41: 1125-1136.

19. Huwait EA and Al-Ghamdi MA: Protective role of carnitine synergized with vitamin $\mathrm{E}$ against isoproterenol induced cardiac infarction in rats in Afr J Tradit Complement Altern Med. (2017) 14(2): 25-32.

20. Rajadurai $M$ and Stanely Mainzen Prince P: Preventive effect of naringin on lipid peroxides and antioxidants in isoproterenol - induced cardiotoxicity in Wistar rats in biochemical and histopathological evidences in Toxicology. (2006) 228(2-3): 259-268.

21. Palojoki E, Saraste A, Eriksson A, Pulkki K, Kallajoki M, Voipio-Pulkki LM and Tikkanen I: Cardiomyocyte apoptosis and ventricular remodeling after myocardial infarction in rats in Am J Physiol Heart Circ Physiol. (2001) 280(6): H2726-31.

22. Fragasso G, Spoladore R, Cuko A and Palloshi A: Modulation of fatty acids oxidation in heart failure by selective pharmacological inhibition of 3-ketoacyl coenzyme-A thiolase in Curr Clin Pharmacol. (2007) 2: 190-196.

23. Al-Rasheed N M, Al-Oteibi M M, Al-Manee R Z, Al-Shareef S A, Al-Rasheed N M, Hasan I H, Mohamad R A and Mahmoud A M: Simvastatin prevents isoproterenol-induced cardiac hypertrophy through modulation of the JAK/ STAT pathway in Drug Des Devel Ther. (2015) 9: 3217-3229.

24. Maranhão RC, Guido MC, de Lima AD, Tavares ER, Marques AF, Tavares de Melo MD, Nicolau JC, Salemi VM and Kalil-Filho R: Methotrexate carried in lipid core nanoparticles reduces myocardial infarction size and improves cardiac function in rats in Int J Nano medicine. (2017) 12:3767-3784.

25. Passino C, Barison A, Vergaro G, Gabutti A, Borrelli C, Emdin M and Clerico A: Markers of fibrosis, inflamma $\neg$ tion, and remodeling pathways in heart failure in Clin Chim Acta. (2015) 443: 29-38.

26. Boudoulas KD and Hatzopoulos AK: Cardiac repair and regeneration: the Rubik's cube of cell therapy for heart disease in Dis Model Mech. (2009) 2(7-8): 344-358.

27. Kwak HH, Kim IR, Kim HJ, Park BS and Yu SB: Mangostin induces apoptosis and cell cycle arrest in oral squamous cell carcinoma cell. evid based complement in Altern Med. (2016) 2016: 5352412.

28. Dungir SG, Katja DG and Kamu VS: Anti-oxidant activity and fenolic extract from Manggosteen peel extract (Garciniamangostana L) in J Mipa Unsrat Online. (2012) 1: 11-15.

29. Buelna-Chontal M, Correa F, Hernández-Reséndiz $\mathrm{S}$, Zazueta C and Pedraza-Chaverri J: Protective effect of $\alpha$-mangostin on cardiac reperfusion damage by attenuation of oxidative stress in J Med Food. (2011) 14(11):1370-1374.

30. Devi Sampath P and Vijayaraghavan $\mathrm{K}$ :Cardioprotectiveeffect of alpha-mangostin, a xanthone derivative from mangosteen on tissue defense system against isoproterenol- induced myocardial infarction in rats in J. Biochem Mol Toxicol.(2007) 21(6), 336-339.

31. Palakawong C, Shopanodora P, Pisuchpen S and Phongpaichit S: Antioxidant and antimicrobial activities of crude extract from mangosteen (Garciniamangostana L) part and some essential oils in Int Food Res J. (2010) 17: 583-589.

32. Bumrungpert A, Kalpravidh RW, Chitchumroonchokchai C, Chuang CC, West T, Kennedy A and McIntosh M: Xanthones from 
mangosteen prevent lipopolysaccharide-mediated inflammation and insulin resistance in primary cultures of human adipocytes in J Nutr. (2009) 139(6):1185-1191.

33. Hale SL, Dai W, Dow JS and Kloner RA: Mesenchymal stem cell administration at coronary artery reperfusion in the rat by two delivery routes: a quantitative assessment in Life Sci. (2008) 83 (13-14): 511-515.

34. Dai W, Hale SL, Martin BJ, Kuang JQ, Dow JS, Wold LE and Kloner RA: Allogeneic mesenchymal stem cell transplantation in postinfarcted rat myocardium: short- and long-term effects in Circulation. (2005) 112(2): 214-223.

35. Chen X, Lu M, Ma N, Yin G, Cui C and Zhao S: Dynamic tracking of injected mesenchymal stem cells after myocardial infarction in rats: a serial 7t MRI study in Stem Cells Int. (2016) 2016: 4656539 .

36. Lee JW, Lee SH, Youn YJ, Ahn MS, Kim JY, Yoo BS, Yoon $\mathrm{J}$ and Kwon W: A randomized, openlabel, multicenter trial for the safety and efficacy of adult mesenchymal stem cells after acute myocardial infarction in J Korean Med Sci. (2014) 29: 23-31.

37. Spees JL, Lee RH and Gregory CA: Mechanisms of mesenchymalstem/stromal cell function in Stem Cell Res Ther. (2016) 7(1): 125.

38. Singh S, Moirangthem RD, Vaidya A, Jalnapurkar S, Limaye L and Kale V: AKT Signaling prevailing in mesenchymal stromal cells modulates the functionality of hematopoietic stem cells via intercellular communication in Stem Cells. (2016) 34(9): 2354-2367.

39. Mirotsou M, Zhang Z, Deb A, Zhang L, Gnecchi $\mathrm{M}$, Noiseux $\mathrm{N}, \mathrm{Mu} \mathrm{H}$, Pachori A and Dzau V: Secreted frizzled related protein 2 (Sfrp2) is the key Akt-mesenchymal stem cell-released paracrine factor mediating myocardial survival and repair in Proc Natl Acad Sci USA. (2007) 104: 1643-1648.

40. Zhao L, Liu X, Zhang Y, Liang X, Ding Y, Xu $\mathrm{Y}$, Fang $\mathrm{Z}$ and Zhang F: Enhanced cell survival and paracrine effects of mesenchymal stem cells overexpressing hepatocyte growth factor promote cardioprotection in myocardial infarction in Exp Cell Res. (2016) 344: 30-39.

41. Schuster MD, Kocher AA, Seki T, Martens TP, Xiang G, Homma S and Itescu S: Myocardial neovascularization by bone marrow angioblasts results in cardiomyocyte regeneration in Am J Physiol Heart Circ Physiol. (2004) 287: H525-H532.

42. Wang H, Chen H, Feng B, Wang X, He X, Hu R,
Yin $\mathrm{M}$, Wang $\mathrm{W}, \mathrm{Fu} \mathrm{W}$ and $\mathrm{Xu} \mathrm{Z}$ : Isolation and characterization of a Sca-1+/CD31- progenitor cell lineage derived from mouse heart tissue in BMC Biotechnol. (2014) 14: 75.

43. Horiba T, Katsukawa M, Abe K and Nakai Y: Alphamangostin promotes myoblast differentiation by modulating the gene-expression profile in $\mathrm{C} 2 \mathrm{C} 12$ cells in Biosci Biotechnol Biochem. (2014) 78(11):1923-1929.

44. Lee LT, Liu SH, Lin MN, Hu NY, Tsai YF, Shih $\mathrm{YC}$ and Iinuma M: Effects of mangosteen on $\alpha$-sma expression in hsc-t6 cells and liver fibrosis in rats in J Chin Med. (2013) 24(2): 211-222.

45. Usunier B, Benderitter M, Tamarat R and Chapel A: Management of fibrosis: the mesenchymal stromal cells breakthrough in Stem Cells Int. (2014) 2014: 340257.

46. Widyaningsih W, Pramono S, Zulaela, Sugiyanto and Widyarini S: Protection by ethanolic extract from ulvalactuca 1 . against acute myocardial infarction: antioxidant and antiapoptotic activities in Malays J Med Sci. (2017) 24(6): 39-49.

47. Groenning BA, Nilsson JC, Sondergaard L, Fritz-Hansen T and Hildebrandt PR (2000): Antiremodeling effects on the left ventricle during beta-blockade with metoprolol in the treatment of chronic heart failure in J Am Coll Cardiol; 36: 2072-2080.

48. Fang Y, Su T, Qiu X, Mao P, Xu Y, Hu Z, Zhang Y, Zheng X, Xie P and Liu Q: Protective effect of alpha mangostin against oxidative stress inducedretinal cell death in Sci Rep. (2016) 6: 21018.

49. Hu X, Yu SP, Fraser JL, Lu Z, Ogle ME, Wang JA and Wei L: Transplantation of hypoxiapreconditioned mesenchymal stem cells improves infarcted heart function via enhanced survival of implanted cells and angiogenesis in J Thorac Cardiovasc Surg. (2008) 135:799-808.

50. Beckman SA, Chen WC, Tang Y, Proto JD, Mlakar L, Wang B and Huard J:Beneficial effect of mechanical stimulation on the regenerative potential of muscle derived stem cells is lost by inhibiting vascular endothelial growth factor in Arterioscler Thromb Vasc Biol. (2013) 33(8): 2004-2012.

51. Mor F, Quintana FJ and Cohen IR: Angiogenesisinflammation cross-talk: vascular endothelial growth factor is secreted by activated T cells and induces Th1 polarization in J Immunol. (2004) 172(7): 4618-4623.

52. Gorin C, Rochefort GY, Bascetin R, Ying H, Lesieur J, Sadoine J, Beckouche N, Berndt S, Novais A and Lesage M: Priming dental pulp stem cells with 
fibroblast growth factor 2 increases angiogenesis of implanted tissue engineered constructs through hepatocyte growth factor and vascuar endothelial growth factor secretion in Stem Cells Transl Med. (2016) 5(3): 392-404.

53. Oktaviyanti IK, Sargowo D, Widodo MA and Mintaroem K: The effects of administration of mangosteen pericap's ethanolic extract and xanthone on angiogenesis of gastric ulcer healing in wistar rats observed through the increase in the level of NO and VEGF and CD-31 expressions in Indonesian Biomed J. (2011) 3(3): 191.

54. Novosel EC, Kleinhans $\mathrm{C}$ and Kluger PJ: Vascularization is the key challenge in tissue engineering in Adv Drug Deliv Rev. (2011) 63 : 300-311.

55. Tang YL, Zhao Q, Qin X, Shen L, Cheng L, Ge $\mathrm{J}$ and Phillips MI: Paracrine action enhances the effects of autologous mesenchymal stem cell transplantation on vascular regeneration in rat model of myocardial infarction in Ann Thorac Surg. (2005) 80(1): 229-236.

56. Cai M, Shen R, Song L, Lu M, Wang J, Zhao S, Tang Y, Meng X, Li Z and He ZX: Bone marrow mesenchymal stem Cells (BM-mscs) improve heart function in swine myocardial infarction model through Paracrine Effects in Sci Rep. (2016) 6: 28250 . 


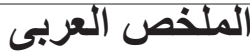

\section{دراسة هستولوجية و هستوكيميائية مناعية عن التأثير المحتمل لعقار

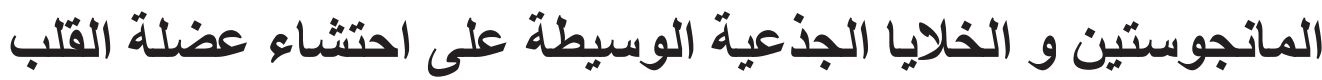

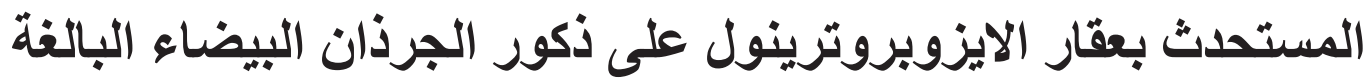

زينب محمد كامل إسماعيل، ماري عطية مرقص، محمد ضياء الدين محمد الشافعي، فاطمة الزهر اء محمد حلمي

$$
\text { قسم الهستولوجيا ـ كلية الطب ــ القصر العيني }
$$

الخلقيه: يعتبر احتشاء عضلة القلب من أهم اسباب مرض القلب الاقفارى والذي قد تؤدي الي الوفاة بالر غم من التقدم

$$
\text { الكبير في التدخلات الطبية. }
$$

الهدف من العمل: يهدف هذا البحث الى التقييم الهستولوجى والمناعى لتأثير نبات المانجوستين والخلايا الجذعية الوسيطة على احتشاء عضلة القلب المستحدث بعقار الايزوبروترينول على ذكور الجرذان البيضاء البالغة. الموادو الأساليب: تم تقسيم55 من ذكور الجرذان البالغة الى: المجموعة الضابطة (المجموعة الاولى) و المجمو عة الثانية (المجمو عة المعالجة بالايزوبروترينول) و المجموعة الثالثة (المجموعة المعالجة بالمانجوستين و عقار الايزوبروترينول) و المجموعة الر ابعة (المجموعة المعالجة بالخلايا الجذعية الوسيطة و عقار الايزوبروترينول) و المجموعة الخامسة (المجموعة المعالجة بالمانجوستين والايزوبروترينول والخلايا الجذعية الوسيطة). لقد تم حقن عقار الايزو تحت الجلد مرتين (250 مجم لكل كجم من الوزن في اليوم), وتم اعطاء عقار المانجوستين عن طريق الفم (18 مجم لكل 200جم من الوزن). كما تم حقن الخلايا الجذعية الوسيطة ( 5 مليون خلية جذعية في1مل من محلول الفوسفات الملحي

$$
\text { الموازن) فى جدار البطين الايسر للقلب. }
$$

لقد تم صباغه العينات القلبية بالهيماتوكسيلين و الايوسين, وصبغة ماسون ثلاثى الالوان و الصبغة الهستو كيميائية المناعية ضد كاسباس3- و عامل نمو بطانة الاو عية الدموية .كما تم قياس متوسط النسبة المئوية لمساحة الياف الكو لاجين، و متوسط النسبة المئوية لمساحة الخلايا المتفاعلة مع الصبغة الهستوكيميائية المناعية كاسباس3- و عامل نمو بطانة

الاوعية الدموية باستخدام جهاز تحليل الصور و التحليل الأحصائي باستخدام مقياس تحليل التباين ANOVA. النتائج: أظهر فحص عينات القلب بالميكرسكوب الضوئى للمجموعة الثانية وجود انتكاس و انقطاع في اغلب الالياف العضلية مع وجود أنوية داكنة و ظهور ارتشاح الخلايا الالتهابية واحتقان فى الاوعية الدموية .و لقد زادت كمية ألياف الكو لاجين بين الالياف العضلية القلبية مع وجود تفاعل مناعى ايجابى قوي فى عينات القلب المصبو غة بصبغة هستوكيميائية مناعية ضد كاسباس3-. لقد أظهرت عينات القلب من المجموعة الثالثة المعالجة بالمانجوستين بعض التحسن فى الالياف العضلية، كما لوحظ ارتشاح عدد قليل من الخلايا الالتهابية بين الالياف العضلية.اما عينات القلب من المجمو عة الر ابعة المعالجة بالخلايا الجذعية الوسيطة فلقد اظهرت تحسن ملحوظ فى الالياف العضليةو أنوية الخلابا مع وجود نقص ذو دلالة احصائية فى مساحة ألياف الكو لاجين وتفاعل مناعى ايجابى ضد عامل نمو بطانة الاوعية الدموية 
و لقد تم الحصول علي افضل النتائج مع جمع الخلايا الجذعية الوسيطة و المانجوستين. الاستنتاج: عقار المانجوستين له تأثير متكامل مع الخلايا الجذعية الوسيطة ضد احتشاء عضلة القلب المستحدث بعقار الايزوبروترينول. 